\title{
The presence of plasmids in Aeromonas hydrophila and its relationship with antimicrobial and heavy metal-resistance profiles
}

\author{
Mariana Ramos Freitas ${ }^{1}$ Naiana Braga Freire ${ }^{1}$ Luciana Jatobá e Silva Peixoto ${ }^{3}$ \\ Samira Teixeira Leal de Oliveira ${ }^{1}$ Renilde Cordeiro de Souza ${ }^{1}$ João José de Simoni Gouveia ${ }^{2,4}$ ○ \\ Mateus Matiuzzi da Costa ${ }^{1,2}$ Gisele Veneroni Gouveia ${ }^{1,2,4^{*}}$ (P)
}

${ }^{1}$ Laboratório de Microbiologia e Imunologia Animal, Universidade Federal do Vale do São Francisco (UNIVASF), Petrolina, PE, Brasil. ${ }^{2}$ Colegiado Acadêmico de Zootecnia, Campus de Ciências Agrárias, Universidade Federal do Vale do São Francisco (UNIVASF), 56300-990, Petrolina, PE, Brasil. E-mail: gisele.veneroni@univasf.edu.br. "Corresponding author.

${ }^{3}$ Departamento de Medicina Veterinária, Instituto Federal de Educação Ciência e Tecnologia do Sertão Pernambucano (IF SERTÃO-PE), Petrolina, PE, Brasil.

${ }^{4}$ Grupo de Pesquisa em Genética Animal Aplicada, Universidade Federal do Vale do São Francisco (UNIVASF), Petrolina, PE, Brasil.

ABSTRACT: Aeromonas hydrophila is a common fish pathogen that causes extensive damage to aquaculture. To develop and implement a more adequate strategy to farm fish, it is crucial to understand the bacterial-resistance levels and their transference dynamics. The objective of this study was to analyze the resistance profile of isolated Aeromonas hydrophila to antimicrobial agents and heavy metals and draw a correlation of the observed profiles with the presence of plasmids. Resistance of the isolated bacteria to antimicrobial agents (oxacilin, gentamicin, tetracycline, and nalidixic acid) and heavy metals (cadmium, lead, copper, and manganese) was verified using the minimum bactericidal concentration (MBC) and minimum inhibitory concentration (MIC) standards. The Multiple Antibiotic Resistance Index (MAR Index) was calculated. Plasmids were extracted by using a common methodology described elsewhere. Mann-Whitney Test, implemented in the $R$ environment, was used to determine the correlation between resistance and plasmids presence. A high resistance to almost all antimicrobial agents and heavy metals was observed, except to gentamicin and cadmium. The MAR index results showed resistance to all antimicrobial profiles. Of the isolated bacteria, 14 showed the presence of plasmids. However, no correlation was noted between the resistance profile and the plasmid presence for these isolates, indicating that the genes responsible for resistance to microbial agents and heavy metals are present in the cromossomic DNA, which in turn suggested the possibility of gene transfer between the isolated bacteria. The resistance to heavy metals can be linked to heavy utilization of fertilizers along the Sao Francisco River.

Key words: aquiculture, multiresistance, megaplasmids, cromossomic DNA, integrons.

Presença de plasmídeos em Aeromonas hydrophila e sua relação com perfis de resistência aos antimicrobianos e metais pesados

RESUMO: Bactérias da espécie Aeromonas hydrophila são patógenos que atacam peixes, causando grandes prejuizos à piscicultura. Entender os perfis de resistência dessa bactéria e a capacidade da mesma em transferir tal resistência é importante para implantação de um manejo adequado na produção de peixes. Os objetivos desse estudo foram analisar a resistência de isolados de Aeromonas hydrophila à antimicrobianos e metais pesados e, correlacionar os perfis encontrados com a presença de plasmídeos. A resistência dos isolados aos antimicrobianos (oxacilina, gentamicina, tetraciclina e ácido nalidíxico) e metais pesados (cádmio, chumbo, cobre e manganês) foi verificada pelas técnicas da Concentração Bactericida Mínima (CBM) e Concentração Inibitória Mínima (CIM). Foi calculado o Índice de Resistência Múltipla aos Antimicrobianos (IRMA). Os plasmídeos foram extraídos por metodologias descritas pela literatura. A relação entre a resistência aos antimicrobianos e metais pesados com a presença de plasmideos foi determinada pelo teste de Mann-Whitney utilizando o ambiente $R$. Foi observada alta resistência aos antimicrobianos e metais pesados testados, com exceção à gentamicina e cádmio. No IRMA os isolados apresentaram resistência a todos os perfis de antimicrobianos possiveis. Quatorze isolados apresentaram plasmídeos, mas não foi encontrada relação dos perfis de resistência com a presença destes, o que indica que os genes de resistência a esses compostos estejam presentes no DNA cromossômico. Porém apontam a possibilidade de transferência dos genes de resistência entre os isolados. Estes resultados apontam alta resistência dos isolados e capacidade de transmissão dessa resistência a outras bactérias. A resistência aos metais pesados, pode estar ligada ao uso de fertilizantes nas plantações localizadas próximas as margens do Rio São Francisco.

Palavras-chave: aquicultura, multirresistência, megaplasmídeos, DNA cromossomal, integrons.

\section{INTRODUCTION}

Aquaculture in Brazil is an emerging activity, and future studies on sanitary and environmental impact of this activity are important (RESENDE et al., 2012). The Brazilian northeastern semi-arid region presents a vast territory and environmental conditions that favors the implementation of farming systems for tropical species. The presence of large water reservoirs like Sao Francisco River, man-made irrigation systems, and lakes as well as high temperatures all year long make this region a viable place to farm exotic fish 
species such as Nile tilapia (Oreochromisniloticus), becoming an important economic alternative for the region (MEURER et al., 2009).

However, the intensive fish farming activity can increase the likelihood of spreading bacterial infections (CRUZ et al., 2012). Another issue that significantly affects fish farming is effluent emissions that can contaminate fresh water with biological and chemical agents and increase the concentration of solids and nutrients derived from the unconsumed fish food (MEIRELLES, 2010).

The bacteria of genus Aeromonas are the main pathogen to fish, as they are under severe stress since they are opportunistic pathogens (JANDA; ABBOTT, 2010). The Aeromonas can be found in fresh water, rivers, lakes, estuaries, underground water, and even sewer (JANDA; ABBOTT, 2010).

The concerns regarding resistance to microbial agents has increased significantly once it was discovered that it can be transferred from one bacterial cell to another facilitated by plasmids. Several genes with different functions such as virulence factor determinants, resistance to anti-microbial agents, and resistance to heavy metals and genes of substrate metabolism can be carried by plasmids (SHERLEY et al., 2004). Different types of contamination by heavy metals indicated mechanisms associated with the coselection process of the resistance to anti-microbial agents (BAKER-AUSTIN et al., 2006).

The objectives of the present study were to analyze the resistance to antimicrobials and heavy metals in isolates of Aeromonas hydrophila obtained from the Valley of São Francisco, Brazil as well as to verify the relationship of this resistance with the presence of plasmids.

\section{MATERIALS AND METHODS}

We analyzed 77 isolates of Aeromonas hydrophila from the bacterial inventory at the Animal Microbiology and Immunology Laboratory of UNIVASF, Agrarian Science campus located in Petrolina/PE/Brazil. The isolates were derived from the samples of fish tissues removed from the kidney, tegument, intestine, and lesions of tilapias $(O$. niloticus). The animals were collected at Sobradinho dam, BA-Brazil and from the Bebedouro Project of CODEVASF/PE/Brazil. These isolates were obtained from previous studies that were approved by the ethics committee of UNIVASF (protocol numbers: 0010/220515 and 0006/160812).

In order to determine the resistance of the isolated $A$. hydrophila, 4 antibiotics (oxacilin, gentamicin, tetracycline, and nalidixic acid) and 4 heavy metals (lead, copper, cadmium, and manganese) were used, following the directions of the protocol M7-A4 (NCCLS, 2005) and the directions of PATHAK and GOPAL (2005). Antibiotics and heavy metals were diluted 8-times on micro plates to concentrations of $512 \mu \mathrm{g} / \mathrm{mL}$ to $0.25 \mu \mathrm{g} / \mathrm{mL}$. The BHI broth served as the negative control (-), and BHI broth with bacterial inoculums served as a positive control. The tests were performed in triplicate.

The resistances to antimicrobial agents and heavy metals were analyzed by Multiple Antibiotic Resistance Index (MAR Index) (KRUMPERMAN, 1983). Index value $>0.3$ indicated that the agent was a potential source of transmission of resistance genes by the isolates.

The presence of plasmids in the bacteria cultures was analyzed using two methods: a method based on alkaline lise as described by BIRNBOIM and DOLY (1979) and a method described by KADO and LIU (1981). All of the extracted plasmids were treated with $0.01 \mathrm{mg}$ of Rnase enzyme and then placed in a dry bath at $25^{\circ} \mathrm{C}$ for $20 \mathrm{~min}$. Plasmids were then submitted to electrophoresis using agarose gel at $0.8 \%$ concentration including $3.5 \mu \mathrm{g} / \mathrm{L}$ ethidium bromide dye. All electrophoresis processes were executed with the inclusion of a chromosomal DNA taken from one of the isolates in the study. This chromosomal DNA was included in all of the gels used, with the objective to differentiate chromosomal DNA from mega-plasmids. Only those samples with a different band from the chromosomal DNA were classified as plasmids.

The relationship between the resistance to antimicrobial agents and heavy metals with the presence of plasmids were determined by the Mann-Whitney test using $\mathrm{R}$ environment ( $\mathrm{R}$ Core Team, 2013), considering $p \leq 0.05$. The analyses were conducted individually for each agent and heavy metal.

\section{RESULTS AND DISCUSSIONS}

A high rate of resistance was observed for the tested isolates for all tested substances, except gentamycin, which was effective at $0.25-256 \mu \mathrm{g} / \mathrm{mL}$, with only 7 isolates resistant at all concentrations (Table 1). Cadmium presented a bactericidal activity of $0.25-512 \mu \mathrm{g} / \mathrm{mL}$, with only 10 resistant isolates (Table 2). Oxacilin presented the least inhibitory capability among the antibiotics tested (Table 1). According to the MAR Index recorded, all isolates presented multi-resistance to the tested antimicrobial agents, with MAR Index varying between 0.37 and 1 . KO et al. (1996) reported the sensitivity of Aeromonas 
Table 1 - Minimum bactericidal concentration (MBC) and minimum inhibitory concentration (MIC) of antibiotics against A. hydrophila isolates.

\begin{tabular}{|c|c|c|c|c|c|c|c|c|}
\hline \multirow{2}{*}{ Concentration $(\mu \mathrm{g} / \mathrm{mL})$} & \multicolumn{2}{|c|}{----------Oxacillin------- } & \multicolumn{2}{|c|}{--------Gentamicin------- } & \multicolumn{2}{|c|}{---------Tetracycline------ } & \multicolumn{2}{|c|}{------Nalidíxic Acid------- } \\
\hline & MIC & $\mathrm{MBC}$ & MIC & $\mathrm{MBC}$ & MIC & $\mathrm{MBC}$ & MIC & $\mathrm{MBC}$ \\
\hline 512 & - & 2 & - & - & - & 5 & - & 9 \\
\hline 256 & 1 & - & - & 1 & 4 & 9 & 8 & 12 \\
\hline 128 & 1 & 4 & 1 & 2 & 10 & 4 & 13 & 4 \\
\hline 64 & 4 & 3 & 2 & 3 & 3 & 5 & 4 & 3 \\
\hline 32 & 2 & 1 & 3 & 17 & 4 & 5 & 3 & 9 \\
\hline 16 & 2 & - & 17 & 18 & 5 & 3 & 8 & 9 \\
\hline 8 & - & - & 17 & 16 & 3 & 6 & 10 & 1 \\
\hline 4 & - & - & 19 & 5 & 5 & 3 & - & 3 \\
\hline 2 & - & - & 6 & - & 5 & 2 & 4 & - \\
\hline 1 & - & - & 1 & 1 & 2 & - & - & - \\
\hline 0.5 & - & - & 3 & 1 & 2 & - & - & - \\
\hline 0.25 & - & - & 1 & 6 & - & 1 & - & - \\
\hline No activity & \multicolumn{2}{|c|}{----------67 (87\%)------- } & \multicolumn{2}{|c|}{------------7 (9\%)--------- } & \multicolumn{2}{|c|}{---------34 (44,1\%)-------- } & \multicolumn{2}{|c|}{---------27 (35\%)--------- } \\
\hline Total isolates & \multicolumn{2}{|c|}{-------------77------------- } & \multicolumn{2}{|c|}{--------------77------------ } & \multicolumn{2}{|c|}{--------------77------------- } & \multicolumn{2}{|c|}{----------------77------------ } \\
\hline
\end{tabular}

-No activity.

spp. to gentamycin and sensitivity of $88 \%$ Aeromonas isolates from humans to the antibiotic.

Despite the fact that the antibiotics tested in this study are not permitted for use in fish farming activities (PÁDUA et al., 2012), the resistance observed can be explained by the transference of the resistance genes from the clinical specimens, including the ones reported in human infections and other mammals to environment specimens found in aquatic animals (ARAVENA-ROMÁN et al., 2012). Another explanation to the resistance observed is the contamination of the aquatic environment with urban and agricultural effluents (LUPO et al., 2012; CABELLO et al., 2013).

The resistance of some microbial groups may vary with the environmental conditions at the location they were collected (CHEN et al., 2013; HARNISZ et al., 2015). The level of resistance manly to tetracycline, is an important bio-indicator of anthropogenic alterations HARNISZ, 2013; HARNISZ et al., 2015). In Aeromonas isolates, the resistance to tetracycline is observed along with other antimicrobial drugs, such as chloramphenicol (VOOLAID et al., 2012). In this study, 34 isolates (44.1\%) presented with resistance to this antibiotic, showing that the environment where the fish was collected presents a major alteration in the water quality, since the resistance to antimicrobial agents can be correlated to its persistence in the environment. Drugs such as sulfas, trimethoprim, macrolides, and fluoride quinolones are commonly found in water bodies. Hydrophobic antibiotics such as tetracycline and ciprofloxacin can easily attach to other particles present in the water (VOOLAID et al., 2012). Aeromonas spp. exposure to hospital waste can elevate its resistance profile to antibiotics such as sulfas and, once the resistance is acquired, it can stay stable in the environment (POPOVIC et al., 2015).

A high resistance of the isolates was noted to the tested heavy metals, with cadmium presenting the best inhibitory effects, being effective up to the concentration of $0.25 \mu \mathrm{g} / \mathrm{mL}$ (Table1). AKINBOWALE et al. (2007) analyzed the resistance to heavy metals in 90 samples of Aeromonas spp. and in 129 samples of Pseudomonas spp., where sensibility to cadmium and increased resistance to manganese, copper, and lead were observed. These results are similar to the ones observed in this study. The high resistance of the isolates to heavy metals evaluated could be linked to the use of fertilizers in the plantations along the Sao Francisco River. The agro-industrial activity along the river has created environmental issues since a long time (ZELLHUBER; SIQUEIRA, 2007).

Resistance to lead tends to be higher than to other elements such as zinc, copper, and manganese that serve as enzymatic cofactors (NEETHU et al., 2015). The resistances to zinc, copper, and lead are 
Table 2 - Minimum bactericidal concentration (MBC) and minimum inhibitory concentration (MIC) of heavy metals against $A$. hydrophila isolates.

\begin{tabular}{|c|c|c|c|c|c|c|c|c|}
\hline \multirow{2}{*}{ Concentration $(\mu \mathrm{g} / \mathrm{mL})$} & \multicolumn{2}{|c|}{---------Cadmium---------- } & \multicolumn{2}{|c|}{--------------Lead----------- } & \multicolumn{2}{|c|}{------------Copper----------- } & \multicolumn{2}{|c|}{--------Manganese-------- } \\
\hline & MIC & $\mathrm{MBC}$ & MIC & $\mathrm{MBC}$ & MIC & $\mathrm{MBC}$ & MIC & $\mathrm{MBC}$ \\
\hline 512 & - & 23 & - & - & - & 16 & - & 2 \\
\hline 256 & 22 & 18 & - & - & 15 & - & 2 & 3 \\
\hline 128 & 20 & 14 & - & 1 & 1 & - & 1 & - \\
\hline 64 & 14 & 6 & 1 & - & - & - & 2 & - \\
\hline 32 & 6 & 4 & - & - & - & - & - & - \\
\hline 16 & 3 & 1 & - & - & - & - & - & - \\
\hline 8 & 1 & - & - & - & - & - & - & - \\
\hline 4 & - & - & - & - & - & - & - & - \\
\hline 2 & - & - & - & - & - & - & - & - \\
\hline 1 & - & - & - & - & - & - & - & - \\
\hline 0.5 & - & - & - & - & - & - & - & - \\
\hline 0.25 & 1 & 1 & - & - & - & - & - & - \\
\hline No activity & \multicolumn{2}{|c|}{--------10(7.7\%)-------- } & \multicolumn{2}{|c|}{--------76(98.7\%)-------- } & \multicolumn{2}{|c|}{---------61(79.2\%)------- } & \multicolumn{2}{|c|}{--------72(935\%)------- } \\
\hline Total isolates & \multicolumn{2}{|c|}{----------------77-----------' } & \multicolumn{2}{|c|}{----------------77------------- } & \multicolumn{2}{|c|}{----------------'77------------ } & \multicolumn{2}{|c|}{--------------77------------. } \\
\hline
\end{tabular}

-No activity.

frequently co-selected (CEYLAN; UGUR, 2012). It is expected that, in environments with high concentration of heavy metals, bacteria activate their resistance mechanisms, which are selected within the population and serve as an important indicator of environmental contamination (ROOSA et al., 2014). The heavy metals are also important indicators of anthropogenic actions over the environment (GIBBONS et al., 2014; STALEY et al., 2015).

Among the 77 isolates studied, 14 presented plasmids using alkaline lyse, with 8 isolates classified as mega-plasmids (bigger than the chromosomal DNA). Among the samples evaluated by KADO e LIU (1981), none showed plasmids, indicating that the alkaline lyse is more efficient in identifying plasmids in the Aeromonas isolates. The literature presents that several aquatic bacteria host a wide variety of mobile genetic elements (e.g., plasmids, integrons, transposons) that can be recombined and create bacteria that are more adapted to the environment, including the presence of antibiotics (SORUM et al., 2008; CABELLO et al., 2013). It has long been known that fish pathogenic bacteria may possess genes of antibiotic resistance that are carried by plasmids and which are responsible of transferring them to other bacteria (CABELLO et al., 2016).

No relationship was noted between the resistance profiles and the presence of plasmids. Results do not excluded the possibility of transmission of genes responsible to resistance to antibiotic and heavy metals, rather they only indicate that these genes are not present in the plasmids, but that recombination events can happen and the resistance genes can be transferred to the plasmids present in the bacteria. These results indicated that the genes form part of the chromosomal DNA or in regions of the integrons, which may be responsible for transferring the genes among isolates.

\section{CONCLUSION}

The low sensibility noted at different concentrations of evaluated antibiotics and the high resistance to heavy metals can be justified by their frequent utilization in the study region, highlighting the importance of the careful use of antibiotics in aquaculture activities and the need for controlling fertilizer use in plantations along rivers. Some isolates presented plasmids; however, the presence of these plasmids was not associated to the resistance to antibiotics and heavy metals, which indicated that the responsible genes can be present at the chromosomal DNA in the integrons regions.

\section{DECLARATION OF CONFLICTING OF INTERESTS}

We have no conflicts of interest to declare. The founding sponsors had no role in the design of the study; in the 
collection, analyses, or interpretation of data; in the writing of the manuscript, and in the decision to publish the results.

\section{REFERENCES}

AKINBOWALE, O. L. et al. Antibiotic and heavy metal resistance in motile aeromonads and pseudomonads from rainbow trout (Oncorhynchus mykiss) farms in Australia. International Journal of Antimicrobial Agents, v.30, p.177-182, 2007. Available from: $<$ http:// www.ijaaonline.com/article/S0924-8579(07)00187-2/fulltext $>$. Accessed: Jan. 31, 2018. doi: 10.1016/j.ijantimicag.2007.03.012.

ARAVENA-ROMÁN, M. et al. Antimicrobial susceptibilities of Aeromonas strains isolated from clinical and environmental sources to 26 antimicrobial agents. Antimicrobial Agents Chemotherapy, v.56, n.2, p.1110-1112, 2012. Available from: $<$ https://dx.doi.org/10.1128\%2FAAC.05387-11>. Accessed: Dec. 10, 2016. doi: 10.1128/AAC.05387-11.

BAKER-AUSTIN, C. et al. Co-selection of antibiotic and metal resistance. Trends in Microbiology, v.14, n.4, p.176-82, 2006 Available from: $<$ http://www.sciencedirect.com/science/article/pii/ S0966842X06000515>. Accessed: Dec. 08, 2016. doi: 10.1016/j. tim.2006.02.006.

BIRNBOIM, H. C.; DOLY, J. A rapid alkaline extraction procedure for screening recombinant plasmid DNA. Nucleic Acids Research, v.7, n.6, p.1513-1523, 1979. Available from: <https://www.ncbi. nlm.nih.gov/pmc/articles/PMC342324/>. Accessed: Fev. 02, 2018.

CABELLO, F. C. et al. Aquaculture as yet another environmental gateway to the development and globalisation of antimicrobial resistance. The Lancet Infectious Diseases, v.16, n.7, p.127-133, 2016. Available from: <http://www.thelancet.com/journals/laninf/ article/PIIS1473-3099(16)00100-6>. Accessed: Jan. 10, 2017. doi: $10.1111 / 1462-2920.12134$.

CABELLO, F. C. et al. Antimicrobial use in aquaculture reexamined: its relevance to antimicrobial resistance and to animal and human health. Environmental Microbiology, v.15, p.19171942, 2013. Available from: <http://onlinelibrary.wiley.com/ doi/10.1111/1462-2920.12134/epdf $>$. Accessed: Jan. 10, 2017. doi: $10.1111 / 1462-2920.12134$.

CEYLAN, O.; UGUR, A. Bio-monitoring of heavy metal resistance in Pseudomonas and Pseudomonas related genus. Journal of Biological Environmental Science, v.6, p.233-242, 2012. Available from: <http://jbes.uludag.edu.tr/PDFDOSYALAR/18/ mak04.pdf $>$. Accessed: Nov. 21, 2016.

CHEN, X. M. et al. Understanding molecular mechanisms of durable and non-durable resistance to stripe rust in wheat using a transcriptomics approach. Current Genomics, v.14, p.111126, 2013. Available from: <https://www.ncbi.nlm.nih.gov/ pmc/articles/PMC3637676/>. Accessed: Dec. 20, 2016. doi: 10.2174/1389202911314020004.

CRUZ, P. et al. Use of probiotics in aquaculture. International Scholarly Research Network, v.2012, p.1-13, 2012. Available from: <https://www.ncbi.nlm.nih.gov/pmc/ articles/PMC3671701/>. Accessed: Dec. 20, 2016. doi: 10.5402/2012/916845.

GIBBONS, S. M. et al. Human and environmental impacts on river sediment microbial communities. PLoS One, v.9, n.5, p.1-9, 2014. Available from: <http://journals.plos.org/plosone/ article?id=10.1371/journal.pone.0097435>. Accessed: Dec. 19, 2016. doi: 10.1371/journal.pone.0097435.

HARNISZ, M. Total resistance of native bacteria as an indicator of changes in the water environment. Environmental Pollution, v.174, p.85-92, 2013. Available from: <http://www.sciencedirect. com/science/article/pii/S0269749112004836?via\%3Dihub>. Accessed: Jan. 12, 2017. doi: 10.1016/j.envpol.2012.11.005.

HARNISZ, M. et al. The impact of a freshwater fish farm on the community of tetracycline resistant bacteria and the structure of tetracycline resistance genes in river water. Chemosphere, v.128, p.134-141, 2015. Available from: $<$ http://www.sciencedirect.com/ science/article/pii/S0045653515000752?via\%3Dihub>. Accessed: Jan. 23, 2017. doi: 10.1016 / j.chemosphere.2015.01.035.

JANDA, J. M.; ABBOTT, S. L. The Genus Aeromonas: Taxonomy, Pathogenicity, and Infection. Clinical Microbiology Reviews, v.23, p.35-73, 2010. Available from: $<$ http://cmr.asm.org/content $/ 23 / 1 / 35$. full>. Accessed: Jun. 23, 2017. doi: 10.1128/CMR.00039-09.

KADO, C. I.; LIU, S. T. Rapid procedure for detection and isolation of large and small plasmids. Journal of Bacteriology, v.145, n.3, p.1365-1373, 1981. Available from: <http://jb.asm.org/ content/145/3/1365.long $>$. Accessed: Nov. 10, 2016. doi: 00219193/81/031365-09\$02.00/0.

$\mathrm{KO}, \mathrm{W}$. C. et al. Increasing antibiotic resistance in clinical isolates of Aeromonas strains in Taiwan. Antimicrobial agents and chemotherapy, v.40, n.5, p.1260-1262, 1996. Available from: $<$ http://aac.asm.org/content/40/5/1260.long>. Accessed: Nov. 25, 2016. doi: 0066-4804/96/\$04.0010.

KRUMPERMAN P.H. Multiple antibiotic resistance indexing of Escherichia coli to identify high-risk sources of fecal contamination of foods. Applied and Environmental Microbiology, v.46, p.165-1670, 1983. Available from: <http://aem.asm.org/content/46/1/165.short>. Accessed: Mar. 23, 2017. doi: 0099-2240/83/070165-06\$02.00/0.

LUPO, A. et al. Origin and evolution of antibiotic resistance: the common mechanisms of emergence and spread in water bodies. Frontiers in Microbiology, v.3, n.18, 2012. Available from: $<$ https://www.ncbi.nlm.nih.gov/pmc/articles/PMC3266646/>. Accessed: Dec. 23, 2016. doi: 10.3389/fmicb.2012.00018.

MEIRELLES, F. S. 2010. Estudo epidemiológico das infecções bacterianas em tilápias Oreochromisniloticus (Linnaeus, 1758), cultivadas em Pernambuco. 2010. 77f. Tese (Doutorado em Ciência Veterinária) - Curso de Pós-graduação em Ciência Veterinária, Universidade Federal Rural de Pernambuco.].

MEURER, F. et al. Brown propolis extract in feed as a growth promoter of Nile tilapia (Oreochromis niloticus, Linnaeus 1758) fingerlings. Aquaculture Research, v.40, p.603-608, 2009. Available from: $<$ http://onlinelibrary.wiley.com/doi/10.1111/j.13652109.2008.02139.x/abstract>. Accessed: Jun. 20, 2017. doi: 10.1111/j.1365-2109.2008.02139.x.

NEETHU, C. S. et al. Heavy-metal resistance in Gram-negative bacteria isolated from Kongsfjord, Arctic. Canadian Journal of Microbiology, v.61, p.429-435, 2015. Available from: <http:// www.nrcresearchpress.com/doi/full/10.1139/cjm-2014-0803>. Accessed: Jan. 20, 2017. doi: 10.1139 / cjm-2014-0803.

NCCLS/CLSI (Clinical and Laboratory Standards Institute/National Committee for Clinical Laboratory Standards). 2005. Methods for 
broth dilution susceptibility testing of bacteria isolated from aquatic animals: proposed guide-line. Document M49-P, CLSI/NCCLS, Wayne, PA. Available from: <https://clsi.org/standards/products/ veterinary-medicine/documents/vet04/>. Accessed: Nov. 10, 2016.

PÁDUA, S. B. et al. Alevinos saudáveis: o ponto de partida para uma produção estável. Panorama da Aquicultura, p.30-37, 2012. Available from: <http://www.panoramadaaquicultura.com. br/novosite/?p=1763>. Accessed: Fev. 24, 2017.

PATHAK, S. P.; GOPAL, K. Occurrence of antibiotic and metal resistance in bacteria from organs of riverfish. Environmental research, v.98, p.100-103, 2005. Available from: $<$ http://www.sciencedirect.com/ science/article/pii/S0013935104000970?via\%3Dihub>. Accessed: Fev. 12, 2017. doi: 10.1016/j.envres.2004.05.012.

POPOVIC, N. T. et al. Detection and diversity of aeromonads from treated wastewater and fish inhabiting effluent and downstream waters. Ecotoxicology and Environmental Safety, v.120, p.235242, 2015. Available from: <https://www.sciencedirect.com/ science/article/pii/S0147651315002961?via\%3Dihub>. Accessed: Jan. 31, 2018. doi: 10.1016/j.ecoenv.2015.06.011.

R Core Team (2013). R: A language and environment for statistical computing. R Foundation for Statistical Computing, Vienna, Austria. Available from: <http://www.R-project.org/.>. Accessed: Jan. 31, 2018.

RESENDE, J. A. et al. Multidrug-resistance and toxic metal tolerance of medically important bacteria isolated from an aquaculture system. Microbes and Environments, v.27, n.4, p.449-455, 2012. Available from: <https://www.jstage.jst.go.jp/article/jsme2/27/4/27_ME12049/_ article>. Accessed: Fev. 12, 2017. doi: 10.1264/jsme2.ME12049.

ROOSA, S. et al. Bacterial metal resistance genes and metal bioavailabilityincontaminated sediments. Environmental Pollution, v.189, p.143-151, 2014. Available from: <http://www.sciencedirect. com/science/article/pii/S0269749114000827?via\%3Dihub>. Accessed: Fev. 12, 2017. doi: 10.1016 / j.envpol.2014.02.031.

SHERLEY, M. et al. Evolution of multi-resistance plasmids in Australian clinical isolates of Escherichia coli. Microbiology, v.150, p.1539-1546,2004. Available from:<http://mic.microbiologyresearch. org/content/journal/micro/10.1099/mic.0.26773-0\#tab2>. Accessed: Fev. 20, 2017. doi: 10.1099/mic.0.26773-0.

SORUM, H. Antibiotic resistance associated with veterinary drug use in fish farms. In: Lie Ø. Improving farmed fish quality and safety, Cambridge, UK: Woodhead Publishing, p.157-182, 2008. Available from: $\quad<\mathrm{https}$ ://www.researchgate.net/publication/286122700_ Antibiotic_resistance_associated_with_veterinary_drug_use_in_fish_ farms $>$. Accessed: Jan. 10, 2017. doi: 10.1533/9781845694920.1.157.

STALEY, C. et al. Frequencies of heavymetal resistance are associated with land cover type in the Upper Mississippi River. Science of the Total Environment, v.511, p.461-468, 2015. Available from: <http://www.sciencedirect.com/science/article/ pii/S0048969714017719?via\%3Dihub>. Accessed: Fev. 12, 2017. doi: 10.1016/j.scitotenv.2014.12.069.

VOOLAID, V. et al. Co-occurrence of resistance to different antibiotics among aquatic bactéria. BMC Microbiology, v.12, p.198, 2012. Available from: <https://bmcmicrobiol.biomedcentral. com/articles/10.1186/1471-2180-12-225>. Accessed: Fev. 10, 2017. doi: 10.1186/1471-2180-12-225.

ZELLHUBER, A.; SIQUEIRA, R. Rio São Francisco em descaminho: degradação e revitalização. Cadernos do CEAS, n²27, Salvador, 2007. Available from: <https://cadernosdoceas. ucsal.br/index.php/cadernosdoceas/article/view/124/104>. Accessed: Fev. 10, 2017. 